IZA DP No. 596

Relative Wages, Openness and Skill-Biased Technological Change

Holger Görg

Eric Strobl

October 2002 


\title{
Relative Wages, Openness and Skill-Biased Technological Change
}

\author{
Holger Görg \\ University of Nottingham and IZA Bonn \\ Eric Strobl \\ Université Catholique de Louvain
}

Discussion Paper No. 596

October 2002

\author{
IZA \\ P.O. Box 7240 \\ D-53072 Bonn \\ Germany \\ Tel.: +49-228-3894-0 \\ Fax: +49-228-3894-210 \\ Email: iza@iza.org
}

This Discussion Paper is issued within the framework of IZA's research area Internationalization of Labor Markets. Any opinions expressed here are those of the author(s) and not those of the institute. Research disseminated by IZA may include views on policy, but the institute itself takes no institutional policy positions.

The Institute for the Study of Labor (IZA) in Bonn is a local and virtual international research center and a place of communication between science, politics and business. IZA is an independent, nonprofit limited liability company (Gesellschaft mit beschränkter Haftung) supported by the Deutsche Post AG. The center is associated with the University of Bonn and offers a stimulating research environment through its research networks, research support, and visitors and doctoral programs. IZA engages in (i) original and internationally competitive research in all fields of labor economics, (ii) development of policy concepts, and (iii) dissemination of research results and concepts to the interested public. The current research program deals with (1) mobility and flexibility of labor, (2) internationalization of labor markets, (3) welfare state and labor market, (4) labor markets in transition countries, (5) the future of labor, (6) evaluation of labor market policies and projects and (7) general labor economics.

IZA Discussion Papers often represent preliminary work and are circulated to encourage discussion. Citation of such a paper should account for its provisional character. A revised version may be available on the IZA website (www.iza.org) or directly from the author. 
IZA Discussion Paper No. 596

October 2002

\section{ABSTRACT}

\section{Relative Wages, Openness and Skill-Biased Technological Change*}

Standard neo-classical trade theory predicts that trade liberalisation should cause a fall in wage inequality in developing countries through a decrease in the relative demand for skilled labour. Recent studies of a number of developing countries, however, find evidence to the contrary. Using a panel of manufacturing firms in the 1990s we investigate whether skillbiased technological change induced through imports of technology-intensive capital goods or export activity may provide an explanation for the increase in relative wages of skilled workers in Ghana. Estimates of a skilled worker relative demand equation based on a translog cost function show that changes in technology through a greater inflow of foreign machinery is found to be indeed consistent with skill-biased technological change in Ghana.

JEL Classification: F14, O33, J31

Keywords: wage inequality, trade liberalisation, skill-biased technological change

Corresponding author:

Holger Görg

School of Economics

University of Nottingham

Nottingham NG7 2RD

UK

Tel.: +44 (0) 1158466393

Fax: $+44(0) 1159514159$

Email: holger.gorg@nottingham.ac.uk

\footnotetext{
* We are particularly grateful to the CSAE at Oxford University for the provision of and advice on the data. Oliver Morrissey, Peter Neary, Francis Teal, and participants of the 2001 ETSG conference in Brussels provided helpful comments on earlier drafts of the paper. Any remaining errors are, of course, our own. Holger Görg gratefully acknowledges financial support from the Leverhulme Trust under Programme Grant No. F114/BF.
} 


\section{Relative Wages, Openness and Skill-Biased Technological Change in Ghana}

\section{Section I - Introduction}

There has been considerable interest in the recent literature in the effects of trade and technological change on wages, in particular, relative wages between skilled and unskilled workers. Most of this literature, which is discussed in the extensive surveys by Haskel (2000) and Slaughter (2000a), considers developed countries, with the US and the UK being the most prominent case studies. In both countries recent decades have witnessed increases in relative wages of skilled relative to unskilled workers and it is argued that at least part of this is due to increased trade with relatively low skill abundant (relative to the US and UK) economies. Another explanation put forward to explain rising wage inequality is that the use of new technologies is skill biased, raises the relative demand for skilled labour and thus increases its relative wage (see Chennels and Van Reenen, 1999 for a survey of this literature).

The theoretical rationale for expecting an effect of trade on wage inequality is based on the standard Heckscher-Ohlin trade model or, more precisely, the Stolper-Samuelson theorem. As Slaughter (2000a, p. 131) puts it, one version of this theorem asserts that "[free] trade lowers the real wage of the scarce factor and raises that of the abundant factor compared to autarky". Assuming that developed countries are generally skilled labour abundant, increasing trade with unskilled labour abundant (developing) countries should raise the wage of skilled workers relative to unskilled workers in developed countries. There is some evidence that this is indeed what has happened in developed countries, although, as Haskel (2000) and Slaughter (2000a) find, empirical support for the theorem is not as clear-cut as one might imagine. 
Taking the Stolper-Samuelson theorem at face value also implies an impact on relative wages in developing countries, which are frequently assumed to be abundant in unskilled labour. Increasing trade should here lead to declines in wage inequality as the return to unskilled labour is raised relative to the return to skilled labour (see Krueger, 1990). However, recent evidence on the link of trade and relative wages for some developing countries casts doubt on the validity of this simple application of the Stolper-Samuelson theorem to the case of developing countries. ${ }^{1}$ For instance, Robbins and Gindling (1999) in examining time series evidence of relative wages from household survey data for Costa Rica find that wage inequality increased after trade liberalisation. Beyer et al. (1999) also find rising wage inequality between skilled and unskilled workers after trade liberalisation using household survey data for Chile. Similar discoveries were made by Robbins (1996) for Argentina, Colombia, Malaysia, Mexico, the Philippines, Taiwan and Uruguay where, in general, trade liberalisation in these countries went hand-in-hand with rising wage inequality. Using plant level data for Mexico, Hanson and Harrison (1999) also find evidence of rising wage inequality following reductions of trade barriers which were most dramatic in low skill intensive industries.

One of the main explanations put forward to deal with this discrepancy between traditional theory and empirics is that greater openness intrinsically also brings with it a greater inflow of technology that may be skill biased and thus act to increase the demand for skilled labour despite its relative scarcity (Robbins, 1996; Wood, 1997). This argument has been formalised by Pissarides (1997). He posits that developing countries (South) improve their technological base through learning from the technology available in developed countries (North). Learning takes place through technology transfers either through developing countries' efforts to imitate technologies or through importing capital goods available in the

\footnotetext{
${ }^{1}$ There is, however, some evidence for East Asian countries during the 1970-1980s which appears to be in line
} 
North. $^{2}$ Crucially, both of these activities are assumed to require only skilled labour in the South. Increasing trade between North and South opens up new opportunities for developing countries' producers to learn Northern technologies. Liberalised trade, on the one hand, allows easier imports of technology intensive capital goods from the North while, on the other hand, it allows Southern firms to export to Northern markets and thus, through competition with Northern firms, learn and imitate new technologies. Since the introduction of new technologies in the South requires skilled labour, demand for this skill group increases and, hence, skilled wages may rise. As Pissarides argues, however, the speed of technology transfer slows as the South learns more and more of the Northern technology. Hence, if the transferred production technology is skill neutral the relative advantage to skilled labour which is the only factor used in imitating Northern technology is only temporary. Only if the new technology is skill-biased is there a positive long-term effect on skilled relative to unskilled labour.

Although a number of researchers now subscribe to some variant of this view, the evidence in support of this explanation is by in large speculative or indirect. Using pooled country level data for Argentina, Chile, Colombia, Costa Rica, Malaysia and the Philippines, Robbins (1996) finds positive correlations between the relative demand for skilled labour and GDP as well as the ratio of imported capital stocks over GDP. Also using a time series of country level data, Robbins and Gindling (1999) also find positive correlations between relative demand and imported machinery, and total exports in Costa Rica. While both studies provide

with the Stolper-Samuelson predictions, see Wood (1997) for a discussion.

2 This is somewhat similar to the ideas developed by Vishwasrao and Bosshardt (2001) who look at technology transfer to developing countries and, in particular, estimate the factors that impact on firms' probability of adopting new technologies. Also, the latter channel for technology transfer discussed by Pissarides is similar, yet different to the idea developed by Feenstra and Hanson (1997). They argue that the flow of foreign direct investment (FDI) into a developing country can raise skill levels in that country. The argument here is, however, that imports (i.e., purchases) of capital goods from abroad which are owned by domestic firms can raise the demand for skilled labour. 
evidence suggestive of the importance of imported technology they have to be interpreted with caution due to the high level of aggregation of the analysis. Liu et al. (2001) provide evidence for Taiwanese manufacturing firms that firms which use more advanced production technologies pay higher wages to both non-production (skilled) and production (unskilled) workers, though they do not investigate changes in relative wages or distinguish whether or not technologies are imported from abroad. Tan and Betra (1997) examine the impact of technology on wage inequality across firm sizes in Columbia, Mexico and Taiwan and find that the employer-size-wage effect is higher for skilled workers than for unskilled workers in technology investing firms only (defined as firms that exported, conducted R\&D, and/or provided training for their employees). They argue that the likely explanation for this is that technological change was skill-biased and that larger firms are more likely to be technology intensive.

Given the rather scant evidence on this issue this paper, to the best of our knowledge for the first time, sets out to provide a systematic analysis of the importance of skill-biased imported technology on relative wages in developing countries. We investigate directly whether the inflow of technology at the firm level acted to increase the relative demand for skilled labour in Ghanaian manufacturing. Specifically, using firm level data covering the period 1991 to 1997 we estimate whether imports of capital goods from abroad and export activity (which allows firms to learn and imitate technologies on the export market) acted to increase the relative demand for skilled labour at the firm level.

The Ghanaian economy should be an instructive case study for at least three reasons. First, given its relatively low level of development one would expect Ghana to be far from saturated with new technologies and thus provide a fertile ground for effects a la Pissarides (1997). Second, previous evidence has shown that Ghana, contrary to what standard neo- 
classical trade theory would predict, has been subject to an increase in wage inequality, rather than a fall, after trade liberalization took place in the 1980s. Third, given that most of the papers analysing the determinants of wage inequality in developing countries as cited above focus on Latin American or South East Asian countries an examination of data for an African country provide an extension of the geographical scope of research on this issue.

The paper proceeds as follows. Section II describes briefly trade liberalisation and the trend in relative wages in Ghana. Section III presents the dataset used in the empirical analysis and some summary statistics. Section IV contains the econometric analysis. Finally, Section V concludes.

\section{Section II - Trade Liberalisation and Wages in Ghana}

After a rapid decline in economic performance and, in particular, in the development of external trade relations during the 1970s and early 1980s, which saw the ratio of imports and exports over GDP decline from 16.9 and 19.3 percent in 1970 to 1.9 and 1.9 percent in 1982 (Oduro, 2000, Table 9.2), the Ghanaian government launched a series of economic reforms in 1983. These reforms, known as the Economic Recovery Programme (ERP) and discussed in some detail by Oduro (2000) were intended to improve the performance of the external trade sector by introducing a number of measures aimed at liberalising external trade. As part of the ERP the exchange rate was adjusted downwards, import tariff rates were substantially lowered, import licenses abolished and export incentives, which had in some form been available since 1969 were made considerably more attractive. In the wake of this policy reform both imports

and exports grew considerably; the ratio of imports and exports to GDP increased from the low values in 1982 to 31.8 and 22.6 percent respectively in 1994 (Oduro, 2000, Table 9.4). 
Over the same period wage inequality between skilled and unskilled workers increased in Ghana. From the data presented in Teal (2000, Table 2) one can calculate that between 1992 and 1996 the real wage of unskilled workers decreased by 25.4 percent while the real wage of skilled labour increased by 16.0 percent in Ghanaian manufacturing. This widening of the relative wage differential appears not to be compatible with the standard StolperSamuelson argument, as outlined above, which would predict that wages of unskilled workers should increase relative to skilled wages. We, therefore, evaluate the validity of the argument that imported technology may have led to an increase in the demand for skilled labour in the remainder of the paper.

\section{Section III - Data Set and Summary Statistics}

The data used for our analysis are drawn from the Regional Programme for Enterprise Development (RPED) dataset. The data consists of seven waves of an annual sample of Ghanaian manufacturing firms, covering the years 1991-1997. The initial sample of 200 firms was drawn from the 1987 Ghana Census of Manufacturing Activities, stratified by size, sector and location. The sectors from which the firms were chosen are Food, Textiles and Garments, Wood, and Metal, which together comprise about 70 per cent of total manufacturing employment in Ghana. ${ }^{3}$ When firms closed down over the period they were replaced with firms in the same size, sector and location category.

While each firm was interviewed for information at the firm level, additionally up to ten of its workers, representative of the occupation categories in the firm, were interviewed

\footnotetext{
3 In the sampling large firms were oversampled. However, since there is no reliable source on the actual population of firms, we were not able to use weights for either our summary statistics our econometric estimation.
} 
each year. ${ }^{4}$ The data used in this paper at the firm level are the level of output, the level of exports, the replacement value of the capital stock, the level of investment and its source (foreign or domestic) and purpose, and the number of workers in total and by occupation category. Information from the worker surveys utilized was that related to earnings. All nominal variables were deflated using sector specific deflators.

In order to calculate the relative wage of skilled labour at the firm level we proceeded as follows. Using worker level information on the number of hours worked per week and earnings we first calculated the hourly wage rate for each worker, ${ }^{5}$ and found the yearly average hourly wage rate of each occupation category employed in each firm. ${ }^{6}$ Using the number of employees in each occupation category reported at the firm level we then calculated the (employment weighted) average firm level skilled and unskilled wage rate, where those in management, sales, supervision, administration or technical jobs were categorised as skilled and all others as unskilled workers.

The annual means of the firm level average relative wage rate, skilled worker employment share, and skilled worker share of the wage bill are given in Table 1. As can be seen the relative wage rate of skilled workers more than doubled over our sample period. By 1997, skilled workers in a firm earned on average 3.3 times as much as their unskilled counterparts. In contrast, the average firm level relative share of skilled workers seems to have remained relatively stable. Overall these trends caused an overall rise, although not consistent, in the labour cost share of skilled workers over our sample period.

[Table 1 here]

\footnotetext{
${ }^{4}$ For the latter four years firms and workers were interviewed only in the fifth and seventh wave, but information was asked respectively for the two years prior to these dates.

5 One should note that the hourly wage rate also includes all allowances and hence is a better proxy of compensation than normally available to researchers.
} 
Most importantly for the purpose of this paper, we need proxies measuring the transfer of superior technology from abroad to Ghanaian firms that may have caused biases in the skill composition of labour. Wood (1997) suggests two possible proxies, namely the inflow of advanced foreign capital goods and greater participation on the international output market. Accordingly, greater openness is likely to allow domestic firms to increase imports of capital goods from abroad which, if these come from relatively more developed countries, are likely to embody greater levels of technology than indigenously produced capital. ${ }^{7}$ Hence the use of capital inputs from abroad presumably requires more skilled labour. Greater export activity is likely to increase the level of technology in a firm since in order to compete on the global market in terms of product quality and prices, a firm is likely to have to use similar levels of technologies as firms in other countries. Competing on foreign export markets thus allows firms to assimilate and imitate technologies used in such markets. ${ }^{8}$

To capture these two channels of technology transfer we calculate two variables from the data available to us. First, the data allows one not only to identify whether the purpose of any investment in equipment undertaken was to improve productivity, quality of output, or produce a product, but also whether the equipment was imported from abroad. Hence, we calculate the first variable, INVFOR/Y, as the amount of investment in equipment sourced abroad for the purpose of technological progress relative to the level of output, in a firm in a

\footnotetext{
${ }^{6}$ Where there was no representative worker in an occupation for which the firm reported employees, or the earnings variable was due to missing data not calculable, we used the sector level average in that year.

${ }^{7}$ Such capital inputs may be both used and new. As shown recently by Barba Navaretti et al (2000), in certain instances it may be more efficient for firms in developing countries to acquire used rather than new machinery.

8 The issue of causality is not clear, however. It may also be the case that firms that use more skilled workers are more likely to export (see Bernard and Jensen, 2001). Our regression below therefore only allows us to discover whether or not exports and skill levels are correlated while we will be cautious about infering causality.
} 
particular year. ${ }^{9}$ Our second variable, PEXP, which captures the effect of export activity is defined as the percentage of output exported.

The yearly average firm means of these two proxies are given in Table 2. Accordingly, except for 1996, there appears to be a general increase in the amount of foreign machinery imported for technological progress purposes - at least relative to the earlier years. For PEXP we also find a clear rise in its mean over time. Over the seven years of our sample period, the average firm's percentage of output exported rose from 3 to 11 per cent.

[Table 2 bere]

These increases in aggregate means of both foreign machinery imports and export activity are confirmed by a simple regression of INVFOR/Y and PEXP on a time trend at the firm level; the results of which are reported in Table 3. We find positive and statistically significant positive coefficients on the time trends for both variables suggesting that firms increased their imports of foreign machinery and their export shares over time. The inclusion of sectoral dummies do not change the results - in fact, for the case of INVFOR/Y an F-test suggests that we cannot reject the hypothesis that the sector dummies are jointly equal to zero and should, therefore, not be included.

[Table 3 bere]

\section{Section IV - The Demand for Skilled Workers}

The results thus far have shown that the share of skilled workers in the wage bill, primarily driven by a rise in the relative wage rate, has risen noticeably in Ghana over the

\footnotetext{
${ }^{9}$ In the data set the total level of investment in a year is either classified as foreign sourced or not. Clearly, however, some of the investment may also fall in the other category. Similarly whether the investment is for technological progress or not is a categorical variable. Whether these aspects under- or overestimate the level of investment sourced from abroad for technological progress is unfortunately not determinable from the data.
} 
1990s. We also find some evidence that at the same time the use of technology induced by greater openness has been on an upward trend.

In order to investigate whether these two trends are related we employ the by now standard approach to estimating the relative demand for skilled labour based on the estimation of a translog cost function. This approach has been used widely in the literature on the effects of skill-biased technological change, trade and investment on the skilled-unskilled wage differential. Chennels and Van Reenen (1999) provide a discussion of this approach, while Machin and Van Reenen (1998), Slaughter (2000b), Blonigen and Slaughter (2001) and Head and Ries (2002) are recent examples using this specification. Accordingly, we assume that a firm minimises costs which are described by a translog cost function. Skilled and unskilled labour are the only variable factors of production while capital and output are (quasi-) fixed (in the short run).

Under these assumptions one can write a restricted variable translog cost function for firm $i$ at time $t$ which in general form is:

$$
\mathrm{C}_{\mathrm{it}}=f\left(\log \left(\mathrm{W}[\mathrm{SK}]_{\mathrm{it}}\right), \log \left(\mathrm{W}[\mathrm{US}]_{\mathrm{it}}\right), \log \left(\mathrm{K}_{\mathrm{it}}\right), \log \left(\mathrm{Y}_{\mathrm{it}}\right), \mathrm{TECH}_{\mathrm{it}}\right)
$$

where $\mathrm{C}$ is the Cost function, $\mathrm{W}[\mathrm{SK}]$ is the skilled wage rate, $\mathrm{W}[\mathrm{US}]$ is the unskilled wage rate, $\mathrm{K}$ is the capital stock and $\mathrm{Y}$ is output. TECH is a structural parameter assumed to affect $\mathrm{C}$ and represents our two measures of technology transfer as described above, namely, imported foreign machinery and export activity.

Differentiating the translog cost function in its proper functional form with respect to W[SK $]$ yields (see, for example, Chennels and Van Reenen, 1999) 


$$
\mathrm{SHARE}_{\mathrm{it}}=\varphi_{\mathrm{i}}+\alpha \log \left(\mathrm{K}_{\mathrm{it}}\right)+\beta \log \left(\mathrm{Y}_{\mathrm{it}}\right)+\gamma \mathrm{TECH}_{\mathrm{it}}+\delta \log \left(\mathrm{W}[\mathrm{SK}]_{\mathrm{it}} / \mathrm{W}[\mathrm{US}]_{\mathrm{it}}\right)
$$

where SHARE $=(\delta \mathrm{C} / \delta \mathrm{W}[\mathrm{SK}]) *(\mathrm{~W}[\mathrm{SK}] / \mathrm{C})$ is the share of skilled workers in the wage bill.

Obtaining the stochastic form of (2) by adding a random error term $\mu$ and firstdifferencing (2) in order to purge all time invariant sector and firm specific factors that may be correlated with the regressors we may write

$$
\Delta \mathrm{SHARE}_{\mathrm{it}}=\varphi_{\mathrm{i}}+\alpha \Delta \log \left(\mathrm{K}_{\mathrm{it}}\right)+\beta \Delta \log \left(\mathrm{Y}_{\mathrm{it}}\right)+\gamma \Delta \mathrm{TECH}_{\mathrm{it}}+\log \Delta\left(\mathrm{W}[\mathrm{SK}]_{\mathrm{it}} / \mathrm{W}[\mathrm{US}]_{\mathrm{it}}\right)+\mu_{\mathrm{it}}
$$

One should note that we do not have information on the actual stock of foreign machinery imported for technological progress purposes as a proxy for technology, TECH. However, given that (3) is estimated in first differences we can simply use a measure of change in the stock, namely INVFOR/Y as a first measure of $\triangle \mathrm{TECH}$. The second measure is calculated as the (first difference) change in export propensity.

The first most obvious problem with estimating (3) is that the relative wage rate at the firm level is likely to be endogenous. We thus, in line with the literature as cited above, instead include sector specific time dummies. We thus implicitly assume that movements of the relative wage rate are determined by sector specific shocks and that these are exogenous to the firm level relative labour demand. ${ }^{10}$ Additionally we also, in all specifications, include time specific dummies common to all firms to control for macroeconomic changes and labour supply changes. Their inclusion also allows to control crudely for other factors that have been put forward as possible explanations for the increases in wage inequalities in some developing countries. For example, Wood (1997) makes a strong argument for the role played by new, 
unskilled labour abundant entrants such as China, India and Pakistan, to the world market. Accordingly, these may be relatively unskilled labour abundant to many other developing countries. While we have no empirical data to investigate this issue further it appears, however, unlikely that these new entrants would have a comparative advantage in unskilled labour relative to Ghana given the low development of the Ghanaian Economy.

Our results of estimating (2) without placing any restrictions on the returns to scale of the underlying production technology are given in the first column of Table 4. As can be seen, the negative and significant sign on capital suggests that skilled labour and capital are substitutes in production, while changes in output have no apparent impact on the demand for skilled labour. Including our proxy for the inflow of foreign capital shows that this technological change proxy acts to increase the demand for skilled labour, thus providing support for the skill-biased technical change induced through openness.

In contrast, changes in the export share from year to year do not influence the skill structure of a firm significantly. Possible reasons for this may be that the export share is not a good indicator of the import of new technology, that it is correlated with other uncontrolled for firm specific factors, and/or that the export share only changes significantly over the very long run so that our relatively short panel in its first differenced version is not able to capture such changes.

We also experimented with imposing a constant returns to scale restriction on (2) and (3). As can be seen the capital to output ratio is insignificant in the general specification; moreover, a simple test of constant returns to scale technology can be rejected. Nevertheless, the positive impact of the import foreign capital used for technological progress remains. We

\footnotetext{
10 These dummy variables may of course capture other sector specific shocks that may impact on SHARE.
} 
similarly find that the export share has no effect on the relative demand for skilled labour in this more restricted specification.

\section{[Table 4 bere]}

To investigate the possible impact on the skill structure of Ghanian firms arising from the use of more modern technology due to trade liberalization over the longer run we estimated (3) for two year rather than annual changes. While we would have ideally liked to use longer term changes, this was not a feasible option with our data which only cover seven years. Calculating three year or longer annual changes would have unfeasibly reduced our sample size. Calculating two year changes meant that, given the flow nature of INVFOR, we used the sum of investment in foreign machinery for technological progress purpose between two year periods while for the other variables we calculated the differences between $t$ and $t+2$. The results of the long run estimations, which are reported in Table 5 are in line with those found for the annual specification except for the fact that a constant returns to scale restriction cannot be rejected - namely, the inflow of foreign machinery acts to increase the relative demand for skilled labour while the firm's export share has no significant effect.

\section{[Table 5 bere]}

\section{Section V - Conclusion}

Evidence on wage inequality in developing countries indicates that, contrary to predictions of neo-classical trade theory, returns to skill have increased after trade liberalization. Ghana is no exception to this finding - despite drastic changes in protection in the 1980s, relative wages of skilled workers continue to rise. Using an employer-employee matched data set of manufacturing firms we investigated whether the transfer of technology from abroad provides a plausible explanation for this phenomenon in Ghana. 
Our empirical results show that the purchase of foreign machinery for technological progress purposes has indeed raised the relative demand for skilled labour, as measured by its share in the wage bill. In contrast, greater participation in the world output market via exporting activity did not play a direct role in the skill composition of manufacturing firms in Ghana. Thus we find support for skill biased technological change only if we use a direct measure of the change in technology at the firm level.

Finally, one should note, however, that we are not able to rule out other explanations for the discrepancy between standard neo-classical trade theory and recent empirical evidence, as, for example, the relatively recent entry of a number of larger unskilled labour abundant economies onto the world market. Such explanations are not necessarily mutually exclusive to the one examined here, and thus assessing their relative role, if any, should be a direction of future research. 


\section{References}

Barba Navaretti, G., I. Soloaga and W. Takacs (2000) "Vintage technologies and skill constraints: evidence from U.S. exports of new and used machines", World Bank Economic Review, 14, pp. 91-109.

Bernard, A.B. and J.B. Jensen (2001) "Why some firms export", NBER Working Paper No. 8349.

Beyer, H., P. Rojas and R. Vergara (1999) "Trade liberalization and wage inequality", Journal of Development Economics, 59, pp. 103-123.

Blonigen, B.A. and M.J. Slaughter (2001) "Foreign-affiliate activity and U.S. skill upgrading", Review of Economics and Statistics, 83, 362-376.

Chennels, L and J. Van Reenen (1999) "Has technology hurt less skilled workers? An econometric survey of the effects of technical change on the structure of pay and jobs" Working Paper W99/27, Institute for Fiscal Studies, London.

Feenstra, R.C. and G.H. Hanson (1997) "Foreign direct investment and relative wages: evidence from Mexico's maquiladoras", Journal of International Economics, 42, 371-393.

Hanson, G.H. and A. Harrison (1999) "Trade liberalization and wage inequality in Mexico", Industrial and Labor Relations Review, 52, pp. 271-288.

Haskel, J.E. (2000) "Trade and labor approaches to wage inequality", Review of International Economics, 8, 397-408.

Head, K. and J. Ries (2002) "Offshore production and skill upgrading by Japanese manufacturing firms", Journal of International Economics, 58, 81-105.

Krueger, A.O. (1990) "The relationship between trade, employment, and development" in G. Ranis and T.P. Schultz (eds.) The state of development economics: progress and perspectives, Cambridge M.A., Blackwell, pp. 357-385.

Liu, J., M. Tsou and J.K. Hammitt (2001) "The impact of advanced technology adoption on wage structures: evidence from Taiwan manufacturing firms", Economica, 68, pp. 359-378.

Machin, S. and J. Van Reenen (1998) "Technology and changes in skill structure: evidence from seven OECD countries”, Quarterly Journal of Economics, 113, pp. 1215-1244.

Oduro, A.D. (2000) "Performance of the external trade sector since 1970" in E. Aryeetey, J. Harrigan and M. Nissanke (eds.) Economic reforms in Ghana: the miracle \& the mirage, Oxford, James Currey, pp. 168-184.

Pissarides, C.A. (1997) "Learning by trading and the returns to human capital in developing countries", World Bank Economic Review, 11, pp. 17-32.

Robbins, D.J. (1996) "HOS hits facts: facts win; evidence on trade and wages in the developing world", mimeo, Harvard Institute for International Development.

Robbins, D. and T.H. Gindling (1999) "Trade liberalization and the relative wages for moreskilled workers in Costa Rica", Review of Development Economics, 3, pp. 140-154. 
Slaughter, M.J. (2000a) "What are the results of product-price studies and what can we learn from their differences?” in R.C. Feenstra (ed.) The impact of international trade on wages, Chicago, University of Chicago Press, pp. 129-165.

Slaughter, M.J. (2000b) "Production transfer within multinational enterprises and American wages", Journal of International Economics, 50, 449-472.

Tan, H. and G. Batra (1997) "Technology and firm size-wage differentials in Columbia, Mexico, and Taiwan (China)", World Bank Economic Review, 11, pp. 59-83.

Teal, F. (2000) "Real wages and the demand for skilled and unskilled male labour in Ghana's manufacturing sector: 1991-1995", Journal of Development Economics, 61, pp. 447-461.

Vishwasrao, S. and W. Bosshardt (2001) "Foreign ownership and technology adoption: evidence from Indian firms", Journal of Development Economics, 65, pp. 367-387.

Wood, A. (1997) "Openness and wage inequality in developing countries: the Latin American challenge to East Asian conventional wisdom", World Bank. Economic Review, 11, pp. 33-57. 
Table 1: Summary Statistics Of Skilled Workers

\begin{tabular}{lccc}
\hline & Relative Wage & Employment Share & Wage Bill Share \\
\hline $\mathbf{1 9 9 1}$ & 1.36 & 0.28 & 0.36 \\
$\mathbf{1 9 9 2}$ & 1.47 & 0.23 & 0.32 \\
$\mathbf{1 9 9 3}$ & 1.63 & 0.25 & 0.36 \\
$\mathbf{1 9 9 4}$ & 2.26 & 0.24 & 0.42 \\
$\mathbf{1 9 9 5}$ & 2.31 & 0.24 & 0.42 \\
$\mathbf{1 9 9 6}$ & 3.10 & 0.26 & 0.48 \\
$\mathbf{1 9 9 7}$ & 3.43 & 0.25 & 0.49 \\
\hline
\end{tabular}

Table 2: Summary Statistics of Technological Change Proxies

\begin{tabular}{ccc}
\hline & $\begin{array}{c}\text { InvFor (\% of } \\
\text { output) }\end{array}$ & $\begin{array}{c}\text { Exports (\% } \\
\text { of output) }\end{array}$ \\
\hline 1991 & --- & 2.70 \\
1992 & 0.91 & 3.45 \\
1993 & 0.66 & 3.05 \\
1994 & 1.41 & 11.42 \\
1995 & 4.48 & 11.42 \\
1996 & 0.55 & 10.16 \\
1997 & 1.83 & 11.24 \\
\hline
\end{tabular}

* A priori there is no obvious reason for the severe fall in 1996. Mean total investment in the same year did not experience a similar drop.

Table 3: Regressions on time trends

\begin{tabular}{ccccc}
\hline & \multicolumn{2}{c}{ INVFOR/Y } & \multicolumn{2}{c}{ PEXP } \\
\hline & (i) & (ii) & (iii) & (iv) \\
\hline trend & 0.003 & 0.003 & 1.545 & 1.430 \\
& $(0.002)^{*}$ & $(0.002)^{*}$ & $(0.351)^{* * *}$ & $(0.338)^{* * *}$ \\
constant & 0.003 & 0.003 & 1.428 & 14.232 \\
& $(0.007)$ & $(0.009)$ & $(1.636)$ & $(2.049)^{* * *}$ \\
Sector dummies & no & yes & no & yes \\
p-value (F-test & & 0.37 & & 0.00 \\
dummies jointly & & & & \\
zero) & & & & \\
\hline
\end{tabular}

Note: $*, * *$, and $* * *$ signify 10,5 , and 1 per cent significance levels, respectively. 
Table 4: Cost Share Equation - Annual Changes

\begin{tabular}{lcccccccc}
\hline & $\mathbf{( 1 )}$ & $\mathbf{( 2 )}$ & $\mathbf{( 3 )}$ & $\mathbf{( 4 )}$ & $\mathbf{( 5 )}$ & $\mathbf{( 6 )}$ & $\mathbf{( 7 )}$ & $\mathbf{( 8 )}$ \\
\hline$\Delta \log (\mathbf{K})$ & $-0.019^{*}$ & -0.015 & $-0.019^{*}$ & -0.015 & --- & --- & -- & --- \\
& $(0.010)$ & $(0.010)$ & $(0.010)$ & $(0.010)$ & & & & \\
$\Delta \log (\mathbf{Y})$ & -0.016 & -0.018 & -0.017 & -0.017 & --- & --- & --- & -- \\
& $(0.012)$ & $(0.012)$ & $(0.012)$ & $(0.012)$ & & & & \\
$\Delta \log (\mathbf{K} / \mathbf{Y})$ & --- & --- & --- & --- & 0.005 & -0.002 & -0.004 & -0.001 \\
& & & & & $(0.008)$ & $(0.008)$ & $(0.008)$ & $(0.008)$ \\
$\mathbf{I N V F O R} / \mathbf{Y}$ & --- & $0.176^{*}$ & --- & $0.176^{*}$ & --- & $0.181^{*}$ & --- & $0.181^{*}$ \\
& & $(0.103)$ & & $(0.103)$ & & $(0.104)$ & & $(0.104)$ \\
$\Delta \mathbf{P E X P}$ & --- & --- & -0.000 & -0.001 & --- & --- & -0.000 & -0.000 \\
& & & $(0.001)$ & $(0.001)$ & & & $(0.001)$ & $(0.001)$ \\
$\mathbf{C o n s t a n t}$ & $0.120^{* *}$ & -0.091 & 0.129 & 0.072 & $0.133^{* *}$ & 0.072 & 0.137 & $0.200^{*}$ \\
& $(0.056)$ & $(0.114)$ & $(0.103)$ & $(0.132)$ & $(0.056)$ & $(0.132)$ & $(0.104)$ & $(0.115)$ \\
\hline Test CRS $\left(\chi^{2}\right)$ & $7.81^{* * *}$ & $5.08^{* *}$ & $5.97^{* *}$ & $5.08^{* *}$ & --- & --- & --- & --- \\
Firms & 144 & 145 & 141 & 140 & 144 & 145 & 141 & 140 \\
Observations & 520 & 482 & 509 & 472 & 520 & 482 & 509 & 472 \\
$\mathbf{R}-s q u a r e d$ & 0.11 & 0.13 & 0.11 & 0.13 & 0.10 & 0.12 & 0.10 & 0.12 \\
F-Test & $2.43^{* * *}$ & $2.56^{* * *}$ & $2.28^{* * *}$ & $2.43^{* * *}$ & $2.25^{* * *}$ & $2.43^{* * *}$ & $2.12^{* * *}$ & $2.31^{* * *}$ \\
\hline
\end{tabular}

Notes:

(1) regressions include sector specific and general time dummies

(2) *, **, and $* * *$ signify 10,5 , and 1 per cent significance levels, respectively.

Table 5: Cost Share Equation - Two Year Changes

\begin{tabular}{lcccccc}
\hline & $\mathbf{( 1 )}$ & $\mathbf{( 2 )}$ & $\mathbf{( 3 )}$ & $\mathbf{( 4 )}$ & $\mathbf{( 5 )}$ & $\mathbf{( 6 )}$ \\
\hline$\Delta \log (\mathbf{K})$ & -0.028 & -0.027 & -0.029 & --- & --- & --- \\
& $(0.018)$ & $(0.018)$ & $(0.018)$ & & & \\
$\Delta \log (\mathbf{Y})$ & 0.008 & 0.001 & 0.008 & --- & --- & --- \\
& $(0.021)$ & $(0.021)$ & $(0.021)$ & & & \\
$\Delta \log (\mathbf{K} / \mathbf{Y})$ & --- & --- & --- & -0.020 & -0.016 & -0.020 \\
& & & & $(0.015)$ & $(0.015)$ & $(0.015)$ \\
$\mathbf{I N V F O R} / \mathbf{Y}$ & $0.132^{*}$ & --- & $0.132^{*}$ & $0.140^{*}$ & --- & $0.140^{*}$ \\
& $(0.074)$ & & $(0.074)$ & $(0.073)$ & & $(0.073)$ \\
$\Delta \mathbf{P E X P}$ & --- & -0.002 & -0.002 & --- & -0.002 & -0.002 \\
& & $(0.002)$ & $(0.002)$ & & $(0.002)$ & $(0.002)$ \\
Constant & -0.161 & -0.162 & -0.168 & 0.209 & -0.149 & -0.158 \\
& $(0.144)$ & $(0.145)$ & $(0.144)$ & $(0.131)$ & $(0.144)$ & $(0.143)$ \\
\hline Test CRS $\left(\boldsymbol{\chi}^{2}\right)$ & 0.70 & 1.11 & 0.65 & --- & --- & --- \\
Firms & 102 & 96 & 96 & 102 & 96 & 96 \\
Observations & 197 & 191 & 191 & 197 & 191 & 191 \\
$\mathbf{R}-$ squared & 0.14 & 0.14 & 0.15 & 0.14 & 0.13 & 0.15 \\
F-Test & $2.16^{* * *}$ & $2.00^{* * *}$ & $2.10^{* * *}$ & $2.27 * * *$ & $2.07 * * *$ & $2.21 * * *$ \\
\hline
\end{tabular}

Notes:

(1) regressions include sector specific and general time dummies

(2) *, **, and $* * *$ signify 10,5 , and 1 per cent significance levels, respectively. 


\section{IZA Discussion Papers}

\begin{tabular}{|c|c|c|c|c|}
\hline No. & Author(s) & Title & Area & Date \\
\hline 581 & $\begin{array}{l}\text { P. Cahuc } \\
\text { F. Malherbet }\end{array}$ & $\begin{array}{l}\text { Unemployment Compensation Finance and } \\
\text { Labor Market Rigidity }\end{array}$ & 5 & $09 / 02$ \\
\hline 582 & $\begin{array}{l}\text { P. Cahuc } \\
\text { C. Gianella } \\
\text { D. Goux } \\
\text { A. Zylberberg }\end{array}$ & $\begin{array}{l}\text { Equalizing Wage Differences and Bargaining } \\
\text { Power: Evidence from a Panel of French Firms }\end{array}$ & 6 & $09 / 02$ \\
\hline 583 & $\begin{array}{l}\text { P. Cahuc } \\
\text { F. Fontaine }\end{array}$ & $\begin{array}{l}\text { On the Efficiency of Job Search with Social } \\
\text { Networks }\end{array}$ & 5 & $09 / 02$ \\
\hline 584 & $\begin{array}{l}\text { C. J. Heinrich } \\
\text { P. R. Mueser } \\
\text { K. R. Troske }\end{array}$ & $\begin{array}{l}\text { Welfare to Temporary Work: Implications for } \\
\text { Labor Market Outcomes }\end{array}$ & 3 & $09 / 02$ \\
\hline 585 & $\begin{array}{l}\text { M. Cervellati } \\
\text { U. Sunde }\end{array}$ & $\begin{array}{l}\text { Human Capital Formation, Life Expectancy and } \\
\text { the Process of Economic Development }\end{array}$ & 3 & $09 / 02$ \\
\hline 586 & $\begin{array}{l}\text { P. Díaz-Vázquez } \\
\text { D. Snower }\end{array}$ & $\begin{array}{l}\text { On-the Job Training and the Effects of Insider } \\
\text { Power }\end{array}$ & 3 & $09 / 02$ \\
\hline 587 & $\begin{array}{l}\text { H. Bonin } \\
\text { W. Kempe } \\
\text { H. Schneider }\end{array}$ & $\begin{array}{l}\text { Kombilohn oder Workfare? Zur Wirksamkeit } \\
\text { zweier arbeitsmarktpolitischer Strategien }\end{array}$ & 3 & $09 / 02$ \\
\hline 588 & M. Frölich & $\begin{array}{l}\text { Nonparametric IV Estimation of Local Average } \\
\text { Treatment Effects with Covariates }\end{array}$ & 6 & $09 / 02$ \\
\hline 589 & $\begin{array}{l}\text { S. Jurajda } \\
\text { K. Terrell }\end{array}$ & $\begin{array}{l}\text { Job Growth in Early Transition: Comparing Two } \\
\text { Paths }\end{array}$ & 4 & $09 / 02$ \\
\hline 590 & $\begin{array}{l}\text { H. Görg } \\
\text { E. Strobl } \\
\text { F. Walsh }\end{array}$ & $\begin{array}{l}\text { Why Do Foreign-Owned Firms Pay More? } \\
\text { The Role of On-the-Job Training }\end{array}$ & 2 & $10 / 02$ \\
\hline 591 & $\begin{array}{l}\text { H. Görg } \\
\text { E. Strobl }\end{array}$ & $\begin{array}{l}\text { Spillovers From Foreign Firms Through Worker } \\
\text { Mobility: An Empirical Investigation }\end{array}$ & 1 & $10 / 02$ \\
\hline 592 & J. Wagner & $\begin{array}{l}\text { Testing Lazear's Jack-of-All-Trades View of } \\
\text { Entrepreneurship with German Micro Data }\end{array}$ & 5 & $10 / 02$ \\
\hline 593 & $\begin{array}{l}\text { T. K. Bauer } \\
\text { P. J. Dross } \\
\text { J. P. Haisken-DeNew }\end{array}$ & Sheepskin Effects in Japan & 1 & $10 / 02$ \\
\hline 594 & $\begin{array}{l}\text { S. C. Wolter } \\
\text { M. Coradi Vellacott }\end{array}$ & $\begin{array}{l}\text { Sibling Rivalry: A Look at Switzerland with } \\
\text { PISA Data }\end{array}$ & 2 & $10 / 02$ \\
\hline 595 & $\begin{array}{l}\text { W. Arulampalam } \\
\text { A. L Booth } \\
\text { M. L. Bryan }\end{array}$ & $\begin{array}{l}\text { Work-Related Training and the New National } \\
\text { Minimum Wage in Britain }\end{array}$ & 3 & $10 / 02$ \\
\hline 596 & $\begin{array}{l}\text { H. Görg } \\
\text { E. Strobl }\end{array}$ & $\begin{array}{l}\text { Relative Wages, Openness and Skill-Biased } \\
\text { Technological Change }\end{array}$ & 2 & $10 / 02$ \\
\hline
\end{tabular}

An updated list of IZA Discussion Papers is available on the center's homepage www.iza.org. 